\title{
School Principal's Strategy in Developing Teacher's Professional Competencies to Improve Educational Quality
}

\author{
Evy Riany \\ SDN 4 Kota Prabumulih \\ e-mail: evyriany9@gmail.com \\ Edi Harapan \\ Universitas PGRI Palembang \\ e-mail: ehara205@gmail.com \\ Tahrun \\ Universitas PGRI Palembang \\ e-mail: tahrun@univpgri-palembang.ac.id \\ Article History: Received on 1 December 2020, Revised on 5 January 2021, \\ Published on 20 January 2021
}

\begin{abstract}
This study identified the principal's strategy in developing teacher's professional competence. This research used a qualitative approach with descriptive methods. Data collection techniques are carried out through interviews, observation and documentation. The research subjects were the principal and teachers of SD Negeri 1 Kota Prabumulih. The results showed that: (1) in order to improve and develop the professional competence of teachers in SD Negeri 1 Kota Prabumulih, the head seems to implement and implement a strategy in the form of "Supervision"; (2) teacher competence at SD Negeri 1 Kota Prabumulih is quite good. because teachers have been trained to educate, teach, guide, direct, train, assess, and evaluate students, and (3) obstacles faced by school principals in improving the professional competence of SD Negeri 1 Prabumulih City teachers, namely: teachers have a solid job in teaching in the classroom so that the teacher does not pay attention to the supervision carried out by the principal, sometimes less and unscheduled implementation time is caused by the principal's busyness in attending official events and meetings outside of school, and some teachers are still there who are late or do not comply with the stipulations on the right time in making the Lesson Plan.
\end{abstract}

Keywords: Principal, Teacher's Professional Competence, Quality of Education

\section{A. Introduction}

Quality education is not only seen from the quality of its graduates, but also includes how schools are able to meet customer needs in accordance with applicable quality standards. Customers in this case are internal customers (educational staff) and external customers (students, parents, society and graduate users) (Wahjosumidjo, 2010). Education is a planned effort to influence other people, both individuals, groups and communities to do what education practitioners expect (Murkatik et al, 2020). Efforts to improve human resources are an integrated effort with improving the quality of education. Education has a role and strategic function in order to produce the children's creativity (Lian et al, 2018). 
Volume 1 (3) 2020

E-ISSN: 2723-6919 P-ISSN:2746-0827

Teachers in learning must be able to understand the subject matter they teach as a lesson that can develop students 'thinking skills and understand various learning models that can stimulate students' ability to learn with careful teaching planning by the teacher (Sagala, 2015). Professional teachers are believed to be abl to make students think, behave and act creatively (Ruslan et al, 2020). Professional teachers have social responsibility manifested through teacher competence from the social environment and have effective interactive abilities. Human resources must be empowered in information technology to become professional teachers (Rahmadoni, 2018). Teacher who has competent in his field will have a more positive impact on the development of students to understand the subject matter (Budiyono et al, 2020). Teacher competence cannot stand alone, but there are other factors that influence it, namely teaching experience, work ethic, teacher motivation and love for their profession, teacher health, educational background, learning support facilities, education and training (training that is followed), economic conditions. or the level of teacher welfare, and the efforts of the principal (Djamarah, 2010). The less than optimal performance of teachers in schools is not entirely caused by the ability of the teachers themselves. Many factors affect teacher performance, both external and internal factors (Maryati et al, 2020).

In educational organizations the leader of education is the principal. A leader must be required to have the intelligence in mastering the situations and conditions of the organization, so that he is able to implement a program development and mobilize the organizational resources he has. The principal must be able to practice innovations, be able to direct all members and the school as an educational organization into a change in mindset, improve vision and mission by utilizing the talents, skills and abilities of its members (Andriani et al, 2018). The leadership of the principal is very supportive of achieving effective and efficient school management. Leadership is a dynamic force that is important in motivating and coordinating organizations in order to achieve goals through a process of influencing others, both within the organization and outside the organization to achieve the desired goals in certain situations and conditions (Sagala, 2010). Winardi argues that strategy is a pattern of goals, objectives or aims and main policies and plans to achieve these goals (Winardi, 2012). The principal as the leader has a very big role in improving the quality of teachers (Alma, 2008). As educational leaders, school principals have quite heavy duties and responsibilities (Ambarita, 2015). This is in accordance with the results of research from Muklis, namely that school principals in managing institutions and work programs have a positive role in improving the quality of education (Mukhlis, 2017). The principal in addition to carrying out conceptual tasks, namely planning, organizing, solving problems and collaborating with teachers and the community must also be able to carry out practical / technical activities (Wahyudi, 2009). Leadership involves a process of social influence, in this case the deliberate influence carried out by someone on others to structure activities and relationships within a group or organization.

Leadership includes three meanings, namely effort, the ability to run a business, and an authority that makes someone considered capable of leading. Institutional leaders must be able to play an active role and be able to strategically position themselves in directing the institution. The success and effectiveness of a school principal in leading can be pursued by respecting each other, working together and having knowledge about the behavior of subordinates (Rahmadoni, 2018).

The leadership style adopted by the principal will be related to the results and effectiveness of the principal in leading and carrying out the educational process in the school (Astuti et al, 
Volume 1 (3) 2020

E-ISSN: 2723-6919 P-ISSN:2746-0827

2020). The success of the strategy is very much dependent on the ability in leadership to build commitment, connect the right strategy and vision, manage resources that support the implementation of the strategy (Amari, 2013). Supervision is an effort made by the principal in helping teachers to be more able to realize the teaching and learning process. The purpose of this study was to find out and describe the principal's strategy in developing teacher professional competence, to analyze and find out the development of teacher professional competence, and to find the right solution in facing the obstacles or obstacles faced by the principal in developing the professional competence of teachers at SD Negeri 1 Prabumulih City.

\section{B. Methods}

This research was conducted at SD Negeri 1 Kota Prabumulih, located on Jalan Jenderal Sudirman 234, West Prabumulih District in the middle of Prabumulih City. This research was conducted from June to July 2020. The research that will be carried out is in the form of qualitative research with a descriptive approach by limiting research into strategies for principals in developing teacher professional abilities. To obtain data in the field, researchers used several techniques in collecting the data needed in this study, as follows: interviews, observation and documentation.

\section{Results and Discussion}

\section{The Principal's Strategy in Developing Teacher Professional Competence at SD Negeri 1 Prabumulih City}

\section{a. Planning for Academic Supervision by the Principal}

The results of the research on the planning of academic supervision carried out by the principal indicate that the planning of the academic supervision program carried out by the principal is in the good category. The results of this study were also reinforced by the answers of the principal who argued that the academic supervision program was always arranged in detail each semester.

\section{b. Implementation of Academic Supervision by the Principal}

The results of research on the implementation of academic supervision carried out by the principal in teacher teaching planning indicate that the implementation of academic supervision carried out by the principal in teacher teaching planning is in the quite good category. This is because the principal only guides when there are teachers with problems. The school principal does not regularly schedule the implementation of supervision in the guidance of finding teaching resources. Although in fact this program must be carried out continuously in order to support teacher professionalism, the principal still has not implemented the program regularly because the principal thinks the teacher is capable of finding teaching resources, and the learning process has continued to run well.

\section{c. Implementation of Academic Supervision in Teacher Teaching Evaluation}

The results of research on the implementation of academic supervision carried out by the principal in the evaluation of teacher teaching indicate that the implementation of academic 
Volume 1 (3) 2020

E-ISSN: 2723-6919 P-ISSN:2746-0827

supervision by the principal in the evaluation of teacher teaching is quite good. This is because in the implementation of teaching evaluation, the teacher is considered capable of implementing it and the principal provides guidance in evaluating teacher teaching when the teacher experiences difficulties. It can be concluded that the guidance of teachers in teaching evaluation has not been routinely carried out because of the busyness of each party and the lack of time for the implementation of supervision so that supervision is carried out when there are problems from the teacher only.

\section{d. Evaluation and Follow Up Academic Supervision by the Principal}

The results of research on the evaluation and follow-up of academic supervision carried out by the principal in the opinion of the teacher indicate that the implementation of evaluation and follow-up of academic supervision carried out by the principal is quite good. This is due to the busyness of each teacher and sometimes teacher development activities. disrupting class hours so that teachers cannot participate in the program. The implementation of the report on the results of the evaluation of academic supervision is still quite good because even though the supervision result document has been made by the principal, some teachers do not know the written report that has been made by the principal and the principal also rarely communicates the supervision results to the teacher.

\section{Teacher Professional Competence at SD Negeri 1 Prabumulih}

From the above opinions it can be concluded that the components of teacher professional competence are: (1) mastery of teaching material, (2) ability to manage learning, (3) knowledge of evaluation. These three competency groups are basically the result of a teacher's cognitive work. Cognitive as cognition is a part of the human soul that processes information, knowledge, experience, encouragement, feelings, and so on both from outside and from within oneself to form conclusions that produce behavior. From this understanding teachers who do not have a cognitive realm will have difficulty understanding and believing in the benefits of science and capturing the moral messages contained in every science.

The professional competence of teachers is the ability possessed by the teacher which is the result of cognitive work to carry out tasks so that students get optimal learning outcomes, so as to create quality or quality education. These abilities include: (1) mastery of subject matter, (2) ability to manage learning, and (3) knowledge of evaluation.

\section{Constraints and Efforts in Academic Supervision by the Principal}

Based on the research results, the obstacles faced in implementing academic supervision by the principal are as follows: a) the teacher has a solid job in teaching in the classroom so that the teacher does not pay attention to the supervision carried out by the principal; b) the implementation time of supervision is sometimes insufficient and unscheduled due to the busyness of the principal in attending official events and meetings outside of school, and 3) some teachers are still late or not according to the right time provisions in making lesson plans, so that the principal has not carried out regular academic supervision which results in the implementation of academic supervision not fully running well and there is no special agenda in implementing academic supervision. 
In the opinion of the teacher, academic supervision carried out by the principal still encountered various obstacles, including some of the teachers arguing that basically the supervision had been scheduled and carried out by the principal, but due to the principal's busyness and the principal's workload that was too heavy it caused implementation supervision has not been carried out optimally according to existing procedures so that there are some teachers who are supervised only when there are problems.

From the results of the discussion above, it can be concluded that the obstacles faced in the implementation of academic supervision include the large number of teacher work and busy teacher activities so that teachers do not pay attention to the implementation of supervision carried out by the principal and sometimes the implementation time of supervision is insufficient and unscheduled due to the busy head schools while the teachers are supervised so much that sometimes the implementation of supervision is not evenly distributed among all teachers. In addition, the busy activities of school principals have resulted in school principals not carrying out regular academic supervision of teachers and some principals have teaching assignments in class, so that the implementation of academic supervision has not been fully implemented and there is no special agenda in implementing academic supervision. These obstacles can be overcome by the efforts made by the principal in solving these problems. The efforts made by each school vary, including using rest or free time for meetings to discuss problems faced by teachers and school principals taking a direct approach individually through private conversations with each teacher in carrying out academic supervision. In addition, the principal collaborates and communicates with the supervisor to discuss the division of supervision tasks so that the implementation of supervision is more efficient so that the goal of supervision in improving teacher teaching professionalism will be achieved properly.

\section{Conclusion}

From the results of the above discussion, it can be concluded that the principal has implemented and implemented a strategy in the form of "Supervision" well and the professional competence of teachers in SD Negeri 1 is quite good. For the obstacles in this study, there was a teacher, because the teacher was still less disciplined in collecting lesson plans and still lacked attention to the supervision strategy that had been made. And for the solution to the existing obstacles, namely by integrating the principal and teachers so that there is no miss communication in the lesson plans collection schedule and the principal is closer to each individual teacher to motivate his work.

\section{E. Acknowledgement}

Our deepest gratitude goes to the Principal of SDN 1 Kota Prabumulih, Chancellor of the PGRI Palembang University, Director of the PGRI Palembang University Postgraduate Program and the PGRI Palembang University Education Management Study Program who have supported us to do this extraordinary thing. This project is independently funded. We would also like to thank our friends in Education Management who helped us a lot in completing this project in a limited time frame. 


\section{References}

Alma, B. (2008). Guru Profesional Menguasai Metode dan Terampil Mengajar [Professional Teachers Are Good at Teaching Methods and Skilled]. Bandung: Alfabeta.

Amari, S. (2013). Peningkatan Mutu Pendidikan Sekolah Dasar \& Menengah [Improving the Quality of Primary \& Secondary School Education]. Jakarta: Prestasi Pustaka.

Ambarita, A. (2015). Kepemimpinan Kepala Sekolah [Principal Leadership]. Jogjakarta: Graha Ilmu.

Andriani, S., Kesumawati, N., \& Kristiawan, M. (2018). The Influence of the Transformational Leadership and Work Motivation on Teachers Performance. International Journal of Scientific \& Technology Research, 7(7).

Astuti, R. W., Fitria, H., \& Rohana, R. (2020). The Influence of Leadership Styles and Work Motivation on Teacher's Performance. Journal of Social Work and Science Education, 1(2), 105-114. Retrieved from https://ejournal.karinosseff.org/index.php/jswse/article/view/33

Asvio, N., Yamin, M., \& Risnita. (2019). Influence of Leadership Style, Emotional Intelligence and Job Satisfaction toward Organizational Commitment (Survey at SMA Muhammadiyah South Sumatera). International Journal of Scientific \& Technology Research 8 (8).

Budiyono, Lian, B., \& Fitria, H. (2020). The Influence of Principal Supervision and Organizational Climate toward Teacher's Performance. Electronic Research Journal of Social Sciences and Humanities Vol 2: Issue II, Apr - Jun 2020.

Djamarah, S.B. dan Zain. (2010). Strategi Belajar Mengajar [Teaching and Learning Strategies]. Jakarta: Rhineka Cipta.

Lian, B., Kristiawan, M., \& Fitriya, R. (2018). Giving Creativity Room to Students Through the Friendly School's Program. International Journal of Scientific \& Technology Research Volume 7, Issue 7. Retrieved from https://www.ijstr.org/finalprint/july2018/Giving-Creativity-Room-To-Students-Through-The-Friendly-SchoolsProgram.pdf

Maryati, E., Fitria, H., \& Rohana, R. (2020). The Influence of Principal's Leadership Style and Organizational Culture on Teacher's Performance. Journal of Social Work and Science Education, 1(2), 127-139. Retrieved from https://ejournal.karinosseff.org/index.php/jswse/article/view/38

Mukhlis. (2017). Efektifitas Peranan Kepala Sekolah dalam Implementasi Berbasis Sekolah di SMK Muhammadiyah 2 Blora [The Effectiveness of the Principal's Role in SchoolBased Implementation at SMK Muhammadiyah 2 Blora]. Surakarta: Pascasarjana UMS. 
Volume 1 (3) 2020

E-ISSN: 2723-6919 P-ISSN:2746-0827

Murkatik, K., Harapan, E., \& Wardiah, D. (2020). The Influence of Professional and Pedagogic Competence on Teacher's Performance. Journal of Social Work and Science Education, 1(1), 58-69. Retrieved from https://ejournal.karinosseff.org/index.php/jswse/article/view/10

Rahmadoni, J. (2018). Isu Global Manajemen Pembiayaan Pendidikan di SD Indonesian Creative School Pekanbaru [Global Issues of Education Financing Management at SD Indonesian Creative School Pekanbaru]. Jurnal Manajemen, Kepemimpinan dan Supervisi Pendidikan 3(2).

Rahmadoni, J. (2018). Perancangan Simulasi Pembelajaran Kriptografi Klasik Menggunakan Metode Web Based Learning [Designing Classical Cryptography Learning Simulation Using Web Based Learning Method]. INTECOMS: Journal of Information Technology and Computer Science, 1(1), 34-43. https://doi.org/https://doi.org/10.31539/intecoms.v1i1.160

Ruslan, Lian, B., \& Fitria, H. (2020). The Influence of Principal's Situational Leadership and Teacher's Professionalism on Teacher's Performance. International Journal of Progressive Sciences and Technologies (IJPSAT), 20(1). Retrieved from https://ijpsat.ijsht-journals.org/index.php/ijpsat/article/view/1733

Sagala, S. (2010). Supervisi Pembelajaran dalam Profesi Pendidikan [Supervision of Learning in the Educational Profession]. Bandung: Alfabeta.

Sagala, S. (2015). Konsep dan Makna Pembelajaran [Concept and Meaning of Learning]. Bandung: Alfabeta.

Wahjosumidjo. (2010). Kepemimpinan Kepala Sekolah Tinjauan Teoritik dan Permasalahannya [Principal Leadership Overview of Theory and Problems]. Jakarta: PT. Raja Grafindo Persada.

Wahyudi. (2009). Kepemimpinan Kepala Sekolah dalam Organisasi Pembelajar (Learning Organization). Bandung: Alfabeta.

Winardi. (2012). Dasar-dasar Manajemen [Fundamentals of management]. Bandung: Mandar Maju. 